\section{IV.B.4.6 結語}

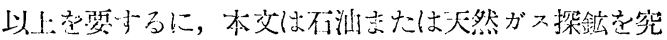

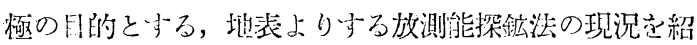

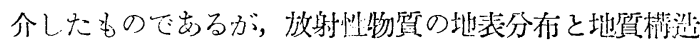

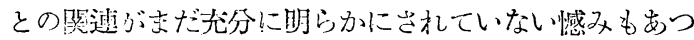
て，成長した探鉙法々はい之ないと思わ机る。今後は事

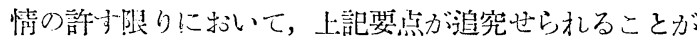
淠志しい。

\section{交献}

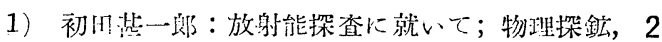
(3) (昭租24和), 1

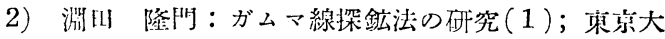
学立地白然科学研究所顶告第 6 号 (昭和25年)，6

3）作野 浚一：最近の放射能探査法について; 物理 探鉣 6 (昭和28年)，21

4) W. L. Russell : The Total Gamma-Ray Activity of Sedimentary Rocks as Indicated by Geiger Counter Determinations ; Geophysics, 9 (1944), 180
5) P. Weaver: A Theory of the Distribution of Radioactivity in Marine Sedimentary Rocks; Geophysics, 7 (1942), 192

R. E. Fearon: Gamma-Ray Well Logging, Niclennics, 4 (1949), 67

V. E. Mckelvey \& M. Nelson: Characteristics of Marine Uranium Bearing Rocks; Ecrin. Genl., 45 (1950), 35

6) E. N. Tiratsoo: Radioactivity Survey in Southwest France; Bull. A. A. P. G., 34 (950), 742

7）物理操鈗調查研究一箵第 2 号，55 56

8). H. G. Botset \& P. Weaver : Radon Content of Soil Gas, Ithysics, 2 (1932), 376

9) J. W. Merritt : Radioactive Oil Survey Techniques, World Oill, 135 (1952), No. 1, 78

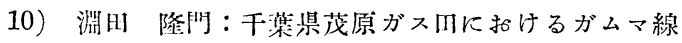
探鉣法に上る潜在断層の探查; 石油技術拹会誌 17 (昭和27年), 68

\title{
IV.B.5 その他の物理探鉱
}

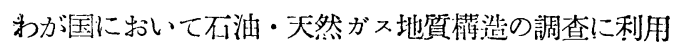
せられる物理探銗法のらち，重力・敏性波 (地震) ・放射 能探鉱は別項に解詮せられている。ここでは，解者ほど でないか，あるいはわが国ではまだ試夕られていない方 法（地表より寸るものに限る）を簡単に紹介する。

\section{IV.B.5.1 磁気探鉱}

傢気探鉱は岩不の磁性に立脚与るものであるので，わ れわれの場合，石润地幦と関速して磁性岩不の分布があ るという特殊の場合でないと利用することはできない。 その上，磁気にはプラン・マイナスの極性があることよ りする欠点, すなわち地下の磁性岩不の地表への磁気的 影響は深さの 3 乘に逆比例するので，深くなると急にわ からなくなる傾向が强い。しかし，米国の油田において はかなりの成果を收めた例为少なくないのでありりわが 国において夕，他の方法に件用の形で参考となつたこと はむる。

ところでこの方面の近年の大きな発展は米国に括け

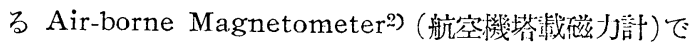
方ろら。芫来の磁力計は磁気科式であつて振動のある所 で做用できないので，この磁力計は鉄の誘㥞率が磁界の
强さによつて変化するのを利用し，地上用精密磁力計級 の測定精度か確保せられている。目的は主として大地啙

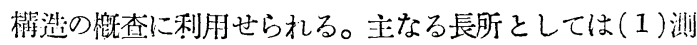
定が極めてはやく能卒的である，(2)したがつて経費が やすい, (3)水上・山地等地形に関係なく実施できる,

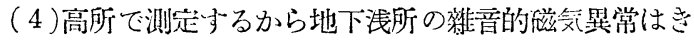
いてこないで，深所の大地質霂浩の影響のみが测定でき るなどがある。一方主な短所としては小さい構泣の探 查に不適当であることである。

\section{IV.B.5.2 電気探 鉱}

地下に打ける岩石比抵抗の分布状態を探查して，地椞

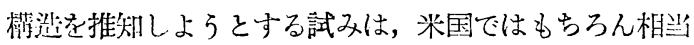
おこなわ机たが，わが国に执いて束主として既知油田㮐 滥に試験されたことがあるふっしかし，いかなる方式に よるにせよ，地表よりェネルギーを供給して電流を流そ らとする限りにおいて，深部への浸透には限度があり， 結果としては重力法や彈性波法の如く重要視されないこ ととなつた。

しかるに第 2 次大戦後米国においては，特に岩塩ド一 ムの探查を主とする Telluric Current Method（地雪 
流法）が注日をむびてきたようである4。この方法は M. Schlumberger5) ぶ 1939年（昭和14）フランスにお いて試夕たのが最初のよらであるが，琶する!との考え は人工的電流の代りに自然的電流索利用して，地下の比 抵抗分有夌知乃らと与るにある。

telluric current といら活と earth current とはす 志りはつきりした区别はないらしいのであるが，ここで は要約していえば，地球表面老渦をなして大きく流狄る 電流のことでもる。表醽流とはいつても，たとえば北

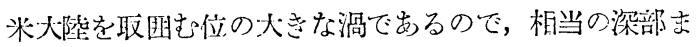
で一様な平均電流密度でおよんでおり，この点ぶこの方 法の狙いである。この電流は数秒から数分程度の週期を 多つて小さく变動するばかりでなく, 磁気日变化と類似 の日変化もする。したがつて测定は面倒であるが，要す るに基準点に対し各測点の記錄を比較する方式による。

岩塩ドームは周囲の岩石より比抵抗が大きいので, 電 流に対してあたか子壁の如く障害となり，電流湶は地表 の方に曲げられドームの上では流線が密集寸る。この状 態を電氛的に探知してドームを見付けようというのがこ の方法の原理である。

\section{交献}

1) Geophysical Case Histories Vol. 1: 米国物理
探鉝学会発行, 1948

2) G. Muffly: The Air-borne Magnetometer, Geophysics, 11 (1946), 321

H. Lundberg: Magnetic Surveys from a Helicopter, Geophysics, 12 (1947), 487

R. D. Wyckoff : The Gulf Air-borne Magnetometer; Geophysics, 13 (1948), 182

H. W. Hoylman: Detection of Salt Domes with the Air-borne Magnetometer; Geophysics, 14 (1949), 447

3）物理探鉣調查研究一覧第 1 号, 21 23

4) R.S. Dahlberg: An Investigation of Natural Earth Currents, (Yeopllysics, (1945), 494

E. Boissonnas \& E. G. Leonardon: Geophysical Exploration by Telluric Current with Special Reference to a Survey of Haynesville Salt Dome, Wood County, Texas ; Geophysacs, 13 (1948), 387

5) M. Schlumberger: The Application of Telluric Currents; Trans. Amer. Geophysics, Union, 20 (1939), 271

\section{IV.B.6 地化学調 查}

本島公司*

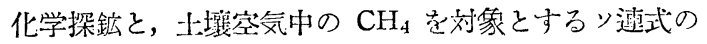
地化学探鉱であのて, 本邦で当主として後者の方式によ る研究が行われた。

昭和20年 (1945)以後, 本邦各地の地下水と共存し, 这 として新生代後期の水成岩層中に成立している $\mathrm{CH}_{4}$ を 主成分と寸る可燃性天然がス調查の装望が多く起り，そ の調查に際してとるべき方法に，往来の地質学的方法の ほかに，上記した地表近くの観測を主とした地化学探鉱 法が採用されたたしかしこの方法は然的に大気による 戝乱作用や，地表近くにおける强烈な生物化学的作用, 人類による影譥等をうけ易く, 测定結果の解析に㕅蜼を きた寸ことがある。そしてこれらの影響は，测定試料探 取の地表からの深度を習すことによつて急涑に減退する ことが期待され，末た実際に奏测に現われるところであ る4)。

このようにして, 主として不汕鉱床の地化学探鉣法に 用いられた方法論が，溶解州岸化水菜鉱床の探查に際し ては，より立体的な地化学的観測に着目されれねばならと2 と気づかれたのである。この考えをさらに桠端に発展さ 